\title{
POLITIK LUAR NEGERI TERHADAP AKUNTANSI DI INDONESIA
}

\section{John F Sonoto}

\section{Intisari}

Artikel ini bertujuan mengulas perkembangan akuntansi sejak masuknya investor asing pada tahun 1967, dikeluarkan Undang-Undang Penanaman Modal Asing (PMA) dan kemudian disusul pada tahun 1968 dengan Undang-Undang Penanaman Modal Dalam Negeri, terjadinya krisis financial secara global sekitar tahun 1997 yang mengguncang perekonomian Negara-negara adikuasa termasuk Asia dan Indonesia muncullah issu IFRS. IFRS sepertinya adalah semacam ketakutan Negara adikuasa sehubungan dengan pesatnya pertumbuhan perdagangan di Asia seperti China yang telah menguasai berabagai industry mulai dari industri makanan sampai industry nuklir dan yang lebih menggemparkan lagi China berencana menjadikan mata uangnya sebagai alat bayar interntasional.

Kata Kunci: IFRS, PMA, krisis financial

\section{PENDAHULUAN}

\section{Perkembangan Praktik Akuntansi di Indonesia}

Praktik akuntansi di Indonesia tidak lepas dari masa penjajahan para Kolonial Belanda dan para lulusan akademi dari Amerika Serikat yang bekerja pada perusahaan-perusahaan Indonesia. Praktik akuntansi di Indonesia dapat ditelusuri pada era penjajahan belanda sekitar tahun 1642 . Jejak yang jelas berkaitan dengan praktik akuntansi di Indonesia dapat ditemui pada tahun 1747 yakni dengan praktik pembukuan yang dilaksanakan amphioen society yang berkedudukan di Jakarta. Pada era belanda mengenalkan sistem pembukuan berpasangan (double-entry bookkeeping) sebagaimana yang dikembangkan oleh Luca Pacioli. Perusahaan VOC milik belanda yang merupakan organisasi kemersil utama selama masa penjajahan memainkan peranan penting dalam praktik bisnis di Indonesia selama era ini.

Selama kurun waktu tahun 1800an sampai awal tahun 1900an kegiatan ekonomi pada masa penjajahan dapat dikatakan mengalami peningkatan yang sangat cepat. Hal ini ditandai dengan dihapuskannya tanam paksa sehingga pengusaha belanda banyak yang menamkan modalnya di Indonesia. Peningkatan kegiatan ekonomi kaum kolonial secara langsung telah mendorong munculnya permintaan akan tenaga akuntan dan juru buku yang telatih. Akibatnya, fungsi auditing mulai dikenalkan di Indonesia pada tahun 1907. Peluang terhadap kebutuhan audit ini akhirnya diambil oleh akuntan belanda dan inggris yang masuk ke Indonesia untuk membantu kegiatan administrasi diperusahaan tekstil dan perusahaan manufaktur. Internal auditor yang pertama kali datang di Indonesia adalah J. W. Labrijin yang sudah berada di Indonesia pada tahun 1896 dan orang pertama yang melaksanakan pekerjaan audit adalah Van Schagen yang dikirim ke Indonesia pada tahun 1907.

Kehadiran seorang Van Schagen merupakan titik tolak berdirinya Jawatan Akuntan Negara (government Accountant Dienst) yang terbentuk pada tahun 1915. Akuntan yang pertama adalah Frese dan Hogeweg yang mendirikan kantor di Indonesia pada tahun 1918. Pendirian kantor ini diikuti kantor akuntan yang lain yakni akuntan H. Y. Vorens pada tahun 1920 dan pendirian Jawatan Akuntan Pajak (Belasting Accountant Dienst). Oleh karena penguasaan terhadap aktifitas ekonomi, maka pada era penjajahan, tidak ada orang Indonesia yang bekerja sebagai akuntan publik. Berbagai pergulatan dengan berbagai upaya dalam menghadapi kaum penjajah yang menguasai ekonomi pribumi akhirnya pada tanggal 21 September 1929 muncullah orang Indonesia 
pertama yang bekerja dibidang akuntansi yakni J. D. Massie, jabatan yang dipercayakan kepadanya adalah sebagai pemegang buku Jawatan Akuntan Pajak

Berbagungnya J. D. Massie, sebagai pemegang buku Jawatan Akuntan Pajak setidaknya menjadi kesempatan emas bagi akuntan lokal dalam hal ini orang pribumi yang kemudian diikuti oleh mundurnya Belanda dari Indonesia pada tahun 1942 1945 untuk mulai menekuni bidang akuntansi. Sejak tahun 1929 pada saat J.D Massie menjadi sebagai pemegang buku Jawatan Akuntan Pajak sampai tahun 1947 setelah kemerdekaan RI hanya baru ada satu orang akuntan yang berbangsa Indonesia yakni Prof. Dr, Abutari.

Sekalipun Belanda telah hengkang dari Indonesia, namun praktik akuntansi model belanda masih digunakan selama era setelah kemerdekaan (era tahun 1950an). Selain praktik di berbagai perusahaan pendidikan pelatihan akuntansi juga masi didominasi oleh sistem akuntansi Belanda. Pada waktu itu, catatan pembukuannya menekankan pada mekanisme debet dan kredit, yang antara lain dijumpai pada pembukuan Amphioen Socyteit bergerak dalam usaha peredaran candu atau morfin (Amphioen) yang merupakan usaha monopoli Belanda. Catatan pembukuannya merupakan modifikasi system Venesia-Italia, dan tidak dijumpai adanya kerangka pemikiran konseptual untuk mengembangkan system pencatatan karena kondisinya sangat menekankan pada praktikpraktik dagang yang semata-mata untuk kepentingan perusahaan Belanda

Dalam berbagai pergerakan menuju pada kemandirian bangsa maka masyarakat mendesak pemerintah RI untuk menasionalisasi perusahaan-perusahaan yang dimiliki Belanda. Pada tahun 1958 proses nasionalisasi atas perusahaan-perusahaan dan pindahnya orang-orang belanda dari Indonesia berdampak pada kelangkaan akuntan dan tenaga ahli pembukuan. Nasionalisasi dan kelangkaan akuntan serta tenaga ahli di tanah air pada akhirnya berpaling ke praktik akuntansi model Amerika. Namun demikian, pada era ini praktik akuntansi model Amerika mampu berbaur dengan akuntansi model Belanda, terutama terjadi di lembaga pemerintah. Makin meningkatnya jumlah institusi pendidikan tinggi yang menawarkan pendidikan akuntansi, seperti pembukaan jurusan akuntansi di Universitas Indonesia 1952, institut ilmu keuangan (Sekolah Tinggi Akuntansi Negara-STAN) 1990, Universitas Padjajaran 1960, Universitas Sumatra Utara 1960, Universitas Airlangga 1960 dan Universitas Gadjah Mada 1964 telah mendorong perganitan praktik akuntansi model Belanda dengan model Amerika pada tahun 1960. Selanjutnya, pada tahun 1970 semua lembaga harus mengadopsi sistem akuntansi model Amerika

Pada pertengahan tahun 1980an, sekelompok teknokrat muncul dan memiliki kepedulian terhadap reformasi ekonomi dan akuntansi. Kelompok tersebut berusaha untuk menciptakan ekonomi yang lebih kompetitif dan lebih berorientasi pada pasar dengan dukungan praktik akuntansi yang lebih baik. Kebijkan kelompok tersebut memperoleh dukungan yang kuat dari investor asing dan lembaga-lembaga internasional. Sebelum perbaikan pasar modal dan pengenalan reformasi akuntansi tahun 1980an dan awal 1990an, dalam praktik banyak ditemui perusahaan yang memiliki tiga jenis pembukuan, satu untuk menunjukkan gambaran sebenarnya dari perusahaan dan untuk dasar pengambilan keputusan; satu untuk menunjukkan hasil yang positif dengan maksud agar dapat digunakan untuk mengajukan pinjaman/kredit dari bank domestic dan asing; dan satu lagi yang menunjukan hasil negative untuk tujuan pajak

Pada awal tahun 1990an, tekanan untuk memperbaiki kualitas pelaporan keuangan muncul seiring dengan terjadinya berbagai skandal pelaporan keuangan yang dapat mempengaruhi kepercayaan dan perilaku investor. Bank Duta adalah contoh salah satu bank yang bermasalah pada zaman pemerintahan presiden Soeharto. Bank Duta go public pada tahun 1990 tetapi gagal mengungkapkan kerugian yang jumlahnya 
besar. Bank Duta juga tidak menginformasikan semua informasi kepada BAPEPAM, auditornya atau underwriternya tentang masalah tersebut. Celakanya lagi, auditor Bank Duta mengeluarkan pendapat wajar tanpa pengecualian. Kasus ini diikuti oleh kasus Plaza Indonesia Realty dan Barito Pasific Timber antara tahun 1992 dan 1993

Berbagai skandal tersebut telah mendorong pemerintah dan Badan berwenang untuk mengeluarkan kebijkan regilasi yang terkai denga pelporan keuangan. Pada tahun 1994, pemerintah melalui IAI mengadopsi seperangkat standar akuntansi keuangan (PSAK). Kedua, pemerintah bekerjasama dengan Bank Dunia (Word Bank) melaksanakan proyek pengembangan akuntansi yang ditunjuk untuk mengembangkan regulasi akuntansi dan melatih profesi akuntansi. Ketiga, pada tahun 1995, pemerintah memuat berbagai aturan berkaitan dengan akuntansi dalam undang-undang Perseroan Terbatas. Dan yang keempat, pada tahun 1995 pemerintah memasukkan aspek akuntansi/pelaporan keuangan kedalam Undang-Undang Pasar Modal
Resesi ekonomi yang ditandai dengan jatuhnya nilai rupiah terhadap dollar pada tahun 1997-1998 mengakibatkan terjadinya tekanan yang meningkat kepada pemerintah untuk memperbaiki kualitas pelaporan keuangan pada tahun 1998, para pengusaha besar (konglomerat) yang mengalami kebangkrutan, sistem perbankan yang colleps, meningkatnay inflasi dan pengangguran memaksa pemerintah bekerjasama dengan IMF dan melakukan negosisasi atas bebagai paket penyelamatan yang ditawarkan IMF. Pada waktu itu kesalahan secara tidak langsung diarahkan pada buruknya praktik akuntansi dan rendahnya kualitas keterbukaan informasi. Untuk menjaga pertanggungjawaban terhadap publik, pemerintah menempatkan bidang akuntansi sebagai sarana startegis sehingga perkembangan akuntansi di Indonesia sangat sarat dengan issu politik bangsa yang oleh penulis secara ringkas perkembangan praktik akuntansi di Indonesia dapat dilihat seperti pada tabel 1 dibawah ini:

Tabel 1

Perkembangan Ekonomi dan Perkembangan Akuntansi di Indonesia sejak era kolonial sampai era setelah Soeharto (era reformasi)

\begin{tabular}{|c|c|c|}
\hline Perkembangan Politik dan Sosial & Perkembangan ekonomi & Perkembangan akuntansi \\
\hline $\begin{array}{l}\text { Era kolonial belanda (1595-1945): } \\
\text { - Belanda menguasai Jawa dan } \\
\text { kepulauan lain } \\
\text { - } \text { Islam menjadi agama mayoritas }\end{array}$ & $\begin{array}{l}\text { Perusahaan Hindia Belanda (VOC) } \\
\text { menguasai perdagangan di } \\
\text { Indonesia. Keterlibatan dan aktifitas } \\
\text { pribumi di perdagangan dibatasi } \\
\text { dengan ketat. Etnis China diberi } \\
\text { hak khusus bidang perdaganagan } \\
\text { dan transportasi air }\end{array}$ & $\begin{array}{l}\text { Belanda mengenalkan akuntansi } \\
\text { di Indonesia. Regulasi akuntansi } \\
\text { yang pertama dikeluarkan tahun } \\
1964 \text { oleh Gubernur Jenderal } \\
\text { Hindia Belanda. Regulasi } \\
\text { tersebut mengatur administrasi } \\
\text { kas dan piutang }\end{array}$ \\
\hline $\begin{array}{l}\text { Era Soekarno (1945-1966): } \\
\text { Indonesia memperoleh kemerdekaan. } \\
\text { Kepemimpinan presiden Soekarna } \\
\text { dekat dengan pemerintah China } \\
\text { (RRC). Tahun } 1965 \text { terjadi kudeta } \\
\text { oleh komunis yang berhasil } \\
\text { digagalkan dan mendorong peran } \\
\text { militer }\end{array}$ & $\begin{array}{l}\text { Dominasi perdagangan oleh } \\
\text { Belanda dan China mendorong } \\
\text { munculnya ketidak adilan di } \\
\text { masyarakt. Akhirnya, Indonesia } \\
\text { memilih pendekatan sosialis dalam } \\
\text { pembangunan yang ditandai dengan } \\
\text { dominasi peran Negara. Tahun } \\
\text { 1958, semua perusahaan milik } \\
\text { Belanda dinasionalisasi dan Warga } \\
\text { Negara Belanda keluar dari } \\
\text { Indonesia }\end{array}$ & $\begin{array}{l}\text { Akademi lulusan Amerika } \\
\text { mengisi kekosongan posisi } \\
\text { akuntan dan sistem akuntansi } \\
\text { dan auditing Amerika } \\
\text { dikenalkan di Indonesia. Baik } \\
\text { akuntansi model Belanda } \\
\text { maupun Amerika digunakan } \\
\text { secara bersama. Ikatan } \\
\text { akuntansi Indonesia didirikan } \\
\text { tahun } 1957 \text { untuk memberi } \\
\text { pedoman dan untuk } \\
\text { mengkoordinasi aktivitas } \\
\text { akuntan }\end{array}$ \\
\hline $\begin{array}{l}\text { Era Soeharto (1966-1998): } \\
\text { Pada tahun } 1966 \text { Soeharto menjabat }\end{array}$ & $\begin{array}{l}\text { Dibawah kepemimpinan Soeharto, } \\
\text { pembangunan ekonomi didasarkan }\end{array}$ & $\begin{array}{l}\text { Terjadi transfer pengetahuan } \\
\text { dan keahlian akuntansi secara }\end{array}$ \\
\hline
\end{tabular}




\begin{tabular}{|l|l|l|}
\hline $\begin{array}{l}\text { sebagi presiden Indonesia yang } \\
\text { kedua. Terpilihnya sebagai presiden } \\
\text { pendekatan kebijakan ekonomi dan } \\
\text { politik yang dilaksanakan adalah } \\
\text { pendekatan konservatifisme }\end{array}$ & $\begin{array}{l}\text { pada pendekatan kapitalis. Investor } \\
\text { asing didorong dan tahun 1967 } \\
\text { dikeluarkan Undang-Undang } \\
\text { Penanaman Modal Asing yang } \\
\text { menghasilkan munculnya } \\
\text { perusahaan asing }\end{array}$ & $\begin{array}{l}\text { langsung dari kantor pusat } \\
\text { perusahaan asing kepada } \\
\text { karyawan Indonesia dan secara } \\
\text { tidak langsung mempengaruhi } \\
\text { aktivitas bisnis. } \\
\text { Tahun 1973, IAI mengadopsi } \\
\text { seperangkat prinsip akuntansi } \\
\text { dan standar auditing serta } \\
\text { professional code of conduct. } \\
\text { Prinsip-prinsip akuntansi } \\
\text { didasarkan pada pedoman } \\
\text { akuntansi yang dipublikasikan } \\
\text { AICPA tahun 1965. } \\
\text { Standar akuntansi internasional } \\
\text { diadopsi tahun 1995 }\end{array}$ \\
& $\begin{array}{l}\text { Tahun 1997-1998 krisis keuangan } \\
\text { yang menimpa Asia juga ikut } \\
\text { berdampak pada ekonomi Indonesia } \\
\text { sehingga banyaknya perusahaan } \\
\text { yang bangkrut }\end{array}$ & $\begin{array}{l}\text { Indonesia berjuang dari kesulitan } \\
\text { ekonomi dan stabilitas sosial }\end{array}$ \\
$\begin{array}{l}\text { Era setelah Soeharto (setelah 1998): } \\
\text { Soeharto dipaksa mengundurkan diri } \\
\text { pada tahun 1998 }\end{array}$ & $\begin{array}{l}\text { Regulasi diperketat untuk } \\
\text { memperbaiki pengungkapan } \\
\text { informasi keuangan }\end{array}$ \\
\hline
\end{tabular}

Perdagangan para kaum kolonial saat itu secara langsung ikut mempengaruhi teknis pencatatan akuntansi di Indonesia atau orang Belanda menyebutkannya sebagai sistem Tata Buku. Sistem akuntansi yang berkemabang saat itu adalah Kontinental dan Anglo Saxon. Kedua sistem ini juga ikut dipengaruhi oleh karena perbagai kepentingan kaum penjajah dan alumnialumni pribumi yang mengikuti pendidikan di luar negeri. Untuk lebih jelas perbedaan kedua sistem akuntansi tersebut, maka dapat diringkas dalam tabel, 2 seperti dibawah ini:

\section{Tabel 2}

\section{Pebedaan akuntansi Sistem Anglo Saxon dan Kontinental}

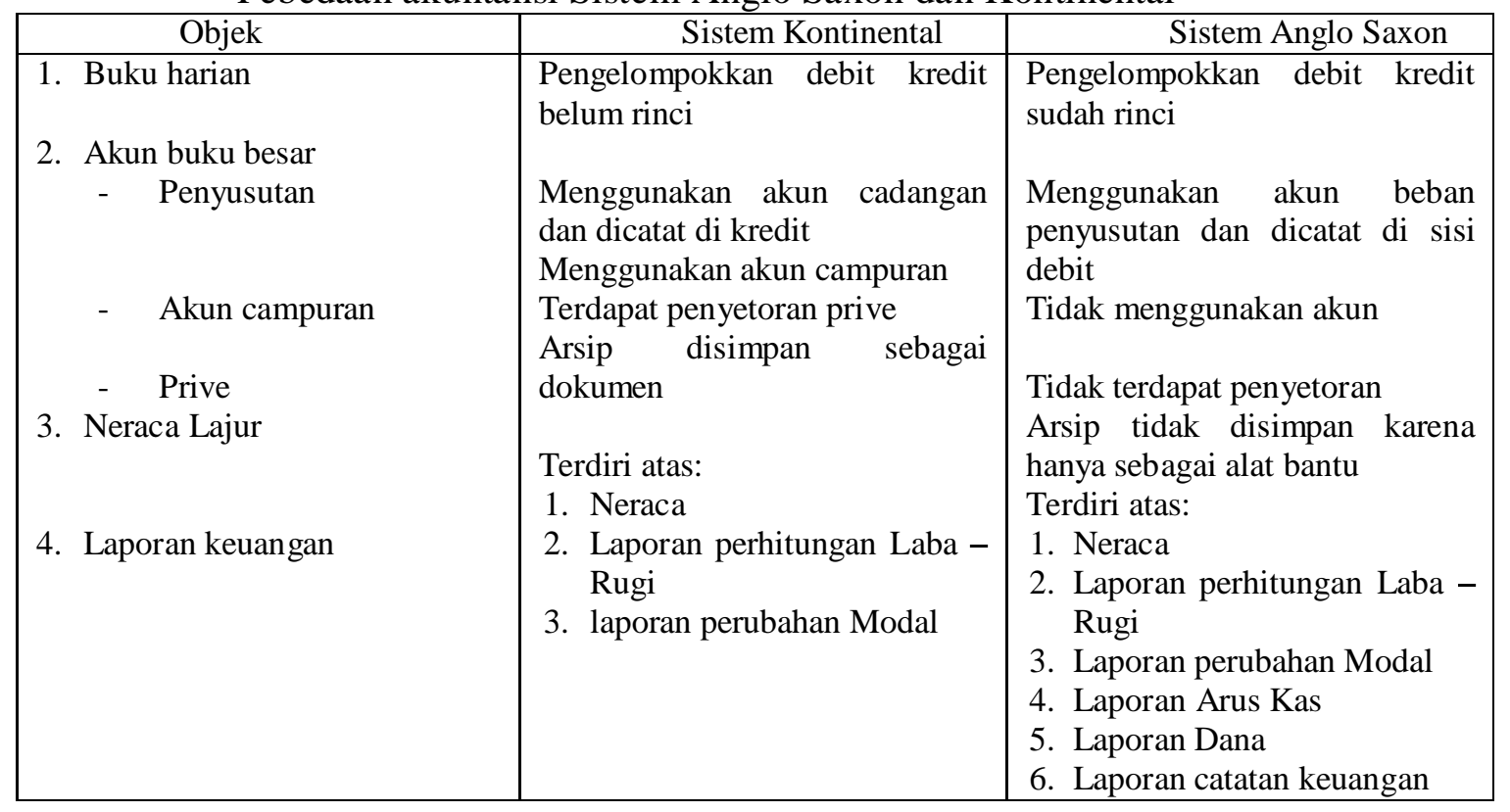

Eksistensi akuntansi Indonesia dalam perkembangannya sangat dipengaruhi oleh organisasi profesi. Pada tahun 1950an, di Indonesia belum ada profesi akuntansi lulusan universitas lokal. Hampir semua akuntan memiliki kualifikasi professional berasal dari Belanda. Munculnya UndangUndang No. 34/1954 tentang pemakaian gelar akuntan merupakan fondasi lahirnya akuntan yang berasal dari univeritas lokal. 
Pada tahun 1957, kelompok pertama mahasiswa akuntansi lulus dari Universitas Indonesia. Namun demikian, kantor akuntan publik milik orang Belanda tidak mengakui kualifikasi mereka. Atas dasar kenyataan tersebut, akuntan lulusan Universitas Indonesia bersama-sama dengan akuntan senior lulusan Belanda mendirikan Ikatan Akuntan Indonesia (IAI) pada tanggal 23 Desember 1957 dan yang menjadi ketua umum IAI pertama kalinya adalah professor Soemarjo Tjitrosidojo seorang akademisi berpendidikan Belanda. Adapun tujuan pendirian IAI waktu itu diantaranya adalah untuk membimbing perkembangan akuntansi serta meningkatkan mutu pendidikan akuntan; meningkatkan mutu pekerjaan akuntan; mempromosikan status profesi akuntansi serta mendukung pembangunan nasional dalam perkembangan pertumbuhan ilmu akuntansi di Indonesia

Kehidupan ekonomi secara global khususnya dibidang financial ikut mempengaruhi permintaan jasa akuntansi dan bermunculan berbagai regulasi luar negeri maupun dalam negeri yang digulirkan demi penyelamatan ekonomi masing-masing negara. Selama tahun 1960an, menurunnya peran kegiatan keuangan mengakibatkan penurunan permintaan jasa akuntansi dan kondisi ini berpengaruh pada perkembangan profesi akuntansi di Indonesia. Namun demikian, perubahan kondisi ekonomi dan politik yang terjadi pada akhir era tersebut, telah mendorong pertumbuhan profesi akuntansi. Profesi akuntansi mulai berkembang cepat sejak tahun 1967 yakni setelah dikeluarkannya Undang-Undang Penanaman Modal Asing dan UndangUndang Penanaman Modal Dalam Negeri 1968. Usaha profesionalisasi IAI mendapat sambutan ketika dilaksanakan konvensi akuntansi yang pertama yakni pada tahun 1969. Hal ini terutama disebabkan oleh adanya Surat Keputusan Menteri Keuangan yang mewajibkan akuntan bersertifikat menjadi anggota IAI

Selanjutnya, pada tahun 1973, IAI membentuk "Komite Norma Pemeriksaan terciptanya perbaikan ujian akuntansi. Yayasan Pengembangan Ilmu Akuntansi Indonesia (YPAI) didirikan pada tahun 1974 untuk mendukung pengembangan profesi melalui program pelatihan dan kegiatan penelitian. Selanjutnya pada tahun 1985 dibentuk Tim Koordinasi Pengembangan Akuntansi (TKPA). Kegiatan TKPA ini didukung sepenuhnya oleh IAI dan didanai oleh Bank Dunia sampai berakhir pada tahun 1993 dengan misinya adalah untuk mengembangkan pendidikan akuntansi, profesi akuntansi, standar profesi dan kode etik profesi.

Kemajuan selanjutnya dapat dilihat pada tahun 1990an ketika Bank Dunia mensponsori Proyek Pengembangan Akuntan (PPA). Melalui proyek ini berbagai standa akuntansi dan auditing dikembangkan, standar profesi diperkuat dan ujian sertifikasi akuntan publik (USAP) mulai dikenalkan. Ujian sertifikasi akuntan publik berstandar internasional diberlakukan sebagai syarat wajib bagi akuntan public yang berpraktik sejak tahun 1997. Pengenalan USAP ini mendapat dukungan penuh dari pemerintah. Hal ini dapat dilihat pada SK Menteri Keuangan No. 43/ KMK. 017/ 1997 yang berisi ketentuan tentang prosedur perizinan, pengawasan dan sanksi bagi akuntan publik yang bermasalah. SK Menteri Keuangan No. 43/ KMK. 017/ 1997 kemudian dalam perkembangannya digantikan dengan SK Menteri Keuangan No. 470/ KMK. 017/ 1999. Setelah empat puluh lima tahun pendirian IAI, IAI berkembang menjadi organisasi profesi yang sangat diakui keberadaannya di Indonesia dan profesi sebagai akuntan public, akuntan manajemen, akuntan pendidik dan akuntan pemerintah

Profesi akuntansi menjadi sorotan public ketika terjadi krisis keuangan di Asia pada tahun 1997 yang ditandai dengan bangkrutnya berbagai perusahaan dan Bank di Indonesia serta berbagai skandal-skandal keuangan lainnya yang sangat sarat dengan isu politik. Hal ini disebabkan perusahaan yang mengalami kebangkrutan tersebut, banyak yang mendapat opini wajar tanpa 
pengecualian (unqualified audit opinies) dari akuntan publik. Pada bulan Juni 1998 Asian Development Bank (ADB) menyetujui Financial Givernance Reform Sector Development Program (FGRSD) untuk mendukung usaha pemerintah mempromosikan dan memperkuat proses pengelolaan (governance) perusahaan disektor public dan keuangan. Kebijakan FGRSD yang disetujui pemerintah adalah usaha untuk menyusun peraturan yang membuat:

1. Auditor bertanggung jawab atas kelalaian dalam melaksanakann audit

2. Direktur bertanggung jawab atas informasi yang salah dalam laporan keuangan dan informasi publik lainnya.

Pada tahun 2001, Departemen Keuangan mengeluarkan Draft Akademik tentang Rancangan Undang-Undang Akuntan Publik yang baru. Dalam draft ini disebutkan bahwa tujuan dibentuknya Undang-Undang Akuntan Publik adalah:

1. Melindungi kepercayaan public yang diberikan kepada akuntan public

2. Memeberikan kerangka hukum yang lebih jelas bagi akuntan public

3. Mendukung pembangunan ekonomi nasional dan menyiapkan akuntan dalam menyongsong era liberisasi jasa akuntan publik

Hal penting dalam RUU AP ini adalah tentang ketentuan yang menyebutkan bahwa Akuntan Publik dan Kantor Akuntan Publik dapat dituntut dengan saksi pidana.

\section{Perkembangan Standar Akuntansi Di Indonesia} Kehadiran Standar Akuntansi Keuangan yang telah teruji oleh waktu dan zaman membuktikan bahwa akuntansi sangat berperan dalam mendukung pertumbuhan ekonomi secara nasional. Para pemakai laporan keuangan seperti, investor, karyawan, pemberi pinjaman, pemasok dan kreditur usaha, pelanggan, pemerintah dan masyarakat sangat membutuhkan informasi sekalipun dengan tingkat kebutuhan yang berbeda diantara mereka. Agar informasi yang diterima para pemakai atau pengguna laporan keuangan adalah informasi yang dapat dipahami, relevan, materialitas, handal, jujur, netral, maka diperlukan sebuah standar yang memadai. supaya lebih dekat mengenal perjalanan panjang perjuangan para pemikirpemikir yang telah meluangkan waktu dan pemikiran cemerlangnya untuk mendesain bentuk dan isi dari Standar Akuntansi Keuangan, berikut akan diuraikan sejarah perkembangan Standar Akuntansi Keuangan.

Dalam sejarah perkembangan Standar Akuntansi Indonesia, terdapat tiga tonggak sejarah. Tonggak sejarah pertama diaktifkannya pasar modal di Indonesia pada tahun 1973, untuk pertama kalinya Ikatan Akuntan Indonesia (IAI) melakukan modifikasi prinsip dan standar akuntansi yang berlaku di Indonesia dalam satu buku “ Prinsip Akuntansi Indonesia atau disingkat dengan sebutan (PAI)"

Tonggak sejarah kedua terjadi pada tahun 1984. Pada masa itu, Komite Prinsip Akuntansi Indonesia atau (PAI)"melakukan revisi secara mendasar PAI 1973 dan mengkodifikasikannya dalam "Prinsip Akuntansi Indonesia 1984".

Berikutnya yang ketiga adalah, pada tahun 1994 IAI melakukan revisi total terhadap PAI 1984 dan melakukan kodifikasi

atau disingkat dengan sebutan SAK per tangel ! Oktober tahur 1994" Gencarry isu globalisasi yang digulirkan Negaranegara mauju maka sejak tahun 1994 itu juga IAI memutuskan untuk melakukan harmonisasi dengan Standar Akuntansi Internasional (SAI) hal ini dilakukan untuk menciptakan iklim investasi yang sehat demi menggenjot perekonomian dalam negeri. Dalam perkembangan selanjutnya ketika krisis moneter yang mengantam seluruh dunia dan peristiwa-peristiwa perusahaanperusahaan raksasa dunia yang runtuh sekejap, akhirnya perubahan dari harmonisasi SAK ke SAI menjadi ke adaptasi SAK ke SAI, kemudian menjadi adopsi dalam rangka konvergensi dengan international financial reporting standards atau disingkat dengan sebutan (IFRS) 
Standar akuntansi yang berkualitas menjadi masalah penting dalam profesi akuntansi dan semua pemakai laporan keuangan. Chariri dan Hendro, 2010 menyatakan bahwa standar akuntansi yang berkualitas akan mempengaruhi kualitas dari laporan keuangan perusahaan. Dengan demikian, standar akuntansi memiliki peran penting bagi pihak penyusun dan semua pemakai laporan keuangan agar timbul keseragaman atau kesamaan interpretasi atas informasi yang terdapat dalam laporan keuangan

Issu konvergensi secara langsung menyita perhatian dewan standard dan pemakai laporan keuangan untuk meningkatkan standar akuntansi keuangan yang berkualitas dalam rangka pengembangan kualitas stuktur pelaporan keuangan global. Untuk dapat menilai berkualitasnya sebuah standar, (Levit 1998; Leisenring, 1998; Regro, 1998; dan DiPiazza et al, 2008) dalam Chariri dan Hendro, 2010 mensyaratkan beberapa hal penting, yang dapat diringkum diantaranya:

1. Standard harus ditulis dengan jelas, dapat dimengerti dan prinsipnya seharusnya dapat diterapkan secara operasional

2. Standar harus dapat diperbandingkan, transparansi dan menyediakan pengungkapan penuh

3. Standar seharusnya menyediakan pedoman pengakuan dan pengukuran yang mendasari transaksi ekonomi

4. Standar seharusnya konsisten dengan pedoman yang diberikan kerangka konseptual

5. Standar seharusnya memungkinan untuk penggunaan penilaian yang wajar

Pertumbuhan ekonomi secara global berdamapak pada peningkatan perkembangan dunia usaha di Indonesia mencermati siklum perekenomian secra global, sehingga pada tahun 2002 Dewan Standar Akuntan Indonesia menerbitkan beberapa revisi yang terkait dengan Standar Akuntan Keuangan yang ada.

Sejak September 1998 hingga April 2002 Dewan Standar Akuntansi Keuangan berhasil mengembangkan standar revisiannya sebagai berikut:

Pertama, menerbitkan empat PSAK revisi, yakni:

- $\quad$ PSAK 55 (revisi 1999) tentang

Akuntansi Instrumen Derivatif dan

Aktivitas Lindung Nilai merevisi PSAK

55 tentang Akuntansi Instrumen

Derivatif dan Aktivitas Lindung Nilai;

- PSAK 31 (revisi 2000) tentang

Akuntansi Perbankan merevisi PSAK 31

(revisi 1994) tentang Akuntansi

Perbankan;

PSAK 5 (revisi 2000) tentang Pelaporan

Segmen merevisi PSAK 5 tentang

Pelaporan Informasi Keuangan Menurut

Segmen; dan

PSAK 19 (revisi 2000) tentang Aktiva

Tidak berwujud merevisi:

- PSAK 19 tentang Aktiva Tak Berwujud;

- PSAK 6 tentang Akuntansi dan Pelaporan bagi Perusahaan dalam Tahap Pengembangan, pada paragraf yang mengatur pengakuan biaya pada perusahaan dalam tahap pengembangan (perintisan usaha); PSAK 17 tentang Akuntansi Penyusutan, pada bagian yang mengatur amortisasi (penyusutan) aktiva tidak berwujud; dan

- PSAK 20 tentang Biaya Riset dan Pengembangan

Kedua, menerbitkan tiga PSAK baru, yakni:

- PSAK 56 tentang Laba Per Saham'

- $\quad$ PSAK 57 tentang Kewajiban Diestimasi, Kewajiban Kontijensi, Aktiva Kontijensi merevisi PSAK 8 tentang Kontijensi dan Peristiwa Setelah Tanggal Neraca, pada bagian yang mengatur mengenai

- $\quad$ PSAK 58 tentang Operasi dalam

Penghentian

Tantangan terhadap kualitas standar akuntansi keuangan saat ini adalah dengan adanya rencana konvergensi IFRS di Indonesia. Sehingga dari revisian 2002 kembali muncul untuk periode 2008-2010. 
Pembahasan: Pengaruh Politik Luar

Negeri Terhadap Perkembangan Praktik dan Standar Akuntansi di Indonesia

Penjelasan perkembangan praktik dan standar akuntansi Indonesia diatas menunjukkan bahwa akuntansi sangat dipengaruhi oleh lingkungan. Choi et. Al (1998;36) dalam Widarsono menyatakan bahwa sejumlah faktor lingkungan diyakini memiliki pengaruh langsung terhadap pengembangan akuntasi, antara lain:

1. Sistem Hukum

Kodifikasi standar-standar dan prosedur akuntansi kelihatannya alami dan cocok dalam Negara-negara yang menganut code law. Sebaliknya, pembentukan kebijakan akuntansi yang non legalitas oleh organsasi-organisasi professional yang berkecipung dalam sektor swasta lebih sesuai dengan sistem yang berlaku dinegara-negara hukum (Common Law). Indonesia disebutsebut sebagai neagra hukum sehingga jika perhatikan akuntansi Indonesia menganut sistem Common Law. Dalam hukum perang atau situasi darurat nasional lainnya, semua aspek fungsi akuntansi mungkin diatur oleh sejumlah pengadilan atau badan pemerintah pusat.

\section{Sistem Politik}

Sistem politik pada suatu Negara pun ikut mewarnai perkembangan akuntansi, karena sistem politik tersebut "mengimpor" dan "mengekspor" standar-standar dan praktik-praktik akuntansi. Sebagai contoh, akuntansi inggris yang ada semasa

negara persemakuran. Belanda melakukan hal yang sama ke Filipina dan Indonesia.

\section{Sistem Kepemilikan Bisnis}

Kepemilikan publik yang besar atas saham-saham perusahaan menyiratkan prinsip-prinsip pelaporan dan pengungkapan akuntansi keuangan yang berbeda dengan perusahaan-perusahaan yang kepemilikannya didominasi oleh keluarga atau bank

4. Perbedaaan besaran dan kompeksitas perusahaan-perusahaan bisnis
Dikotomi yang terjadi antara perusahaan besar dan kecil terus berlanjut, mulai dari masalah asuransi, hingga keseluruh hirarki perusahaan induk-anak, termasuk masalah kompleksitas. Perusahaan konglomerasi besar yang beroperasi dalam lini bisnis yang sangat beragam membutuhkan teknik-teknik pelaporan keuangan yang berbeda dengan perusahaan kecil yang menghasilkan produk tunggal. Perusahaan-perusahaan multinasional juga membutuhkan sistem akuntansi yang berbeda dengan sistem akuntansi perusahaan-perusahaan domestik.

5. Iklim Sosial

Iklim sosial turut memberikan sumbangan dalam pengembangan akuntansi diberbagai belahan dunia. Misalanya, di Perancis mengarah pada pelaporan tanggungjawab sosial, sebaliknya di Swiss masih sangat konservatif sehingga perusahaan-perusahaan besar swiss melaporkan kondisi keuangannya yang relative ringkas.

6. Tingkat Kompetensi Manajemen

Bisnis dan Komunitas Keuangan

Kompetensi atau kemampuan manajen bisnis dan pengguna dari output akuntansi akan sangat menentukan perkembangan akuntansi. Karena secanggih dan sehebat apapun output akuntansi, jika manajemen bisnis dan para pengguna tidak dapat membaca, mengartikan dan memahaminya hal tersebut tidak akan ada gunanya.

\section{Tingkat Campur Tangan Bisnis Legislatif \\ Regulasi mengenai perpajakan} mungkin memerlukan prinsip-prinsip akuntansi tententu. Seperti swedia, dimana kelonggaran pajak tertentu harus dibukukan secara akuntansi sebelum bisa diklaim bagi tujuan pajak; ini juga merupakan situasi bagi penilaian persediaan metode LIFO di AS.

\section{Ada Legalisasi}

Akuntansi Tertentu Dalam beberapa kasus, terdapat peraturan legislative khusus untuk aturan-aturan dan teknik-teknik akuntansi tententu. Di AS, SEC menentukan 
standar-standar pengungkapan dan akuntansi bagi perusahaan-perusahaan besar, dengan mengacu pada FASB .

\section{Kecepatan Inovasi Bisnis}

Semuala, kegiatan marger dan akuisisi tidak diperhitungkan secara akuntansi, namun karena penggabungan bisnis yang begitu popolar di Eropa memaksa akuntansi turut berkembang untuk memenuhi kebutuhan dari mereka yang berkepentingan.

\section{Tahap Pengembangan Ekonomi}

Negara yang masih mengandalkan ekonomi pertanian membutuhkan prinsipprinsip akuntansi yang berbeda dengan Negara industri maju. Di Negara pertanian, tingkat ketergantungan pada kredit dan kontrak bisnis jangaka panjang mungkin masih kecil. Sehingga akuntansi akrual yang canggih tidak berguna dan yang dibutuhkan adalah akuntansi kas sederhana.

\section{Pola Pertumbuhan Ekonomi}

Kondisi perekonomian yang stabil mendorong peningkatan persaingan memperbutkan pasar-pasar yang ada sehingga memerlukan suatu pola akuntansi yang stabil dan akan jauh berbeda pada Negara yang kondisinya sedang mengalami perang berkepanjangan.

\section{Status Pendidikan dan Organisasi \\ Profesional}

Karena ketiadaan profesionalisme akuntansi yang terorganisir dan sumber otoritas akuntansi lokal suatu Negara, standar-standar dari area lain atau Negara lain mungkin digunakan untuk mengisi kekosongan tersebut. Adaptasi faktor-faktor akuntansi dari Inggris merupakan pengaruh lingkungan yang signifikan dalam akuntansi dunia akhir PD II. Sejak saat itu, proses adaptasi internasional beralih ke sumbersumber dari AS. Pengembangan akuntansi, baik yang berasal dari Negara itu sendiri atau yang diadaptasi dari Negara-negara lain, tidak akan sukses kecuali jika kondisikondisi lingkungan seperti yang terdapat dalam daftar diatas dipertimbangkan secara penuh

Akuntansi mengalami perkembangan yang sangat pesat seiring dengan tumbuh dan berkembangnya bisnis surat-surat berharga khususnya bisnis saham pasar modal. Perkembangan pasar modal Indonesia yang pesat dimulai sejak ditetapkannya paketpaket kebijakan oleh pemerintah pada Desember 1987, oktober 1988, dan Desember 1988. Kebijakan-kebijakan tersebut telah meningkatkan kegairahan para pelaku bisnis di pasar modal, sekaligus menarik perhatian para peneliti untuk melakukan penelitian yang berkaitan dengan pasar modal. Kebijakan tersebut juga membuat adanya perubahan mendasar terhadap kegiatan di pasar modal Indonesia.

Perkembangan yang pesat ini semakin didukung dengan swastanisasi Bursa Efek Indonesia (BEI) pada tahun 1992, penerapan Jakarta Automated Trading system pada tahun 1995, dan dikeluarkannya Undangundang No. 8 Tahun 1995 tentang pasar modal yang berlaku efektif mulai Januari 1996. Mekanisme transaksi perdagangan bursa di Indonesia yang dilakukan oleh pasar modal beserta lembaga-lembaga penunjangnya memperoleh kapastian hukum

Menurut Sunariyah dalam Puspitasari, 2010 menyatakan bahwa perkembangan harga saham dipengaruhi beberapa faktor baik internal maupun eksternal. Faktor internal perusahaan yang berpengaruh berasal dari pendapatan per lembar saham, besarnya deviden yang dibagi, kinerja manajemen perusahaan, dan prospek perusahaan di masa yang akan datang. Faktor eksternal yang berpengaruh seperti munculnya gejolak politik pada suatu Negara, perubahan kebijakan moneter dan laju inflasi yang tinggi.

\section{SIMPULAN}

Dari berbagai kajian literatur yang dijelaskan dengan berbagai bukti perjalanan panjang sejarah Perkembangan Praktik Akuntansi dan Standar Akuntansi Keuagan di Indonesia sejak zaman kolonial, era kepemimpinan Presiden Soekarno, Era 
Presiden Soeharto, sampai era reformasi, hingga percaturan PSAK dan ISAK 2011 (konvergensi IFRS) sangat kental dengan pengaruh gejolak politik Negara-negara Maju apalagi jika dihubungkan dengan Pertumbuhan atau perkembangan Pasar Modal (Bursa Efek Indonesia).

Sejak awal perkembangan akuntansi telah dibalut dengan strategi meningkatkan perekonomian dalam negeri dengan mengundang masuknya investor asing sehingga pada tahun 1967 dikeluarkan Undang-Undang Penanaman Modal Asing dan kemudian disusul pada tahun 1968 dengan Undang-Undang Penanaman Modal Dalam Negeri saat itulah kemudian permintaan akan tenaga profesi akuntansi kembali bermunculan setelah Belanda Hengkang dari Indonesia. Selanjutnya ketika krisis financial secara global sekitar tahun 1997 yang mengguncang perekonomian Negara-negara adikuasa termasuk Asia dan Indonesia muncullah issu IFRS. Indonesia dengan berbagai regulasinya berencana melakukan konvergensi IFRS, sehingga dengan optimisnya Indonesia akan melaksanakannya pada tahun 2012. Bagi saya ini adalah politik perdagangan luar negeri khususnya Negara-negara Maju seperti Amerika dengan sekutunya yang mulai ketakutan menghadapi Negara-negara Asia seperti China yang menunjukkan kemampuannya mengenjot ekonomi Nasionalnya. Pesatnya pertumbuhan perdagangan China yang telah menguasai berabagai industry mulai dari industru makanan sampai industry nuklir dan yang lebih menggemparkan lagi China berencana menjadikan mata uangnya sebagai alat bayar interntasional yang akan bersaing dengan Dollar Amerika

Sektor Usaha Kecil Menengah (UKM) membuktikan bahwa UKM memberikan kontribusi besar bagi perekonomian bangsa sehingga ketika krisis financial melanda, UKM justru yang mampu menggenjot perekonomian secara nasional. Sehingga bagi saya jika ditanyakan sejauh mana pengaruh politik luar negeri terhadap Standar Akuntansi Keuangan Indonesia? Ini adalah produk kapitalisasi negara-negara maju yang sukses mempolitisasi perekonomian nasional.

Kita harus kembali melihat pada sejarah perkembangan, disana sangat jelas bahwa setelah pemberlakuan Undangundang Penanaman Modal Asing barulah diikuti dengan pesatnya permintaan tenaga profesi akuntansi dan kemudian berkembang sampai pada pembuatan naskah Standar Akuntansi Keuangan. Sehingga saya sepakat dengan salah satu pendapat Choi et. Al (1998) bahwa Sistem politik pada suatu Negara ikut mewarnai perkembangan akuntansi, karena sistem politik tersebut "mengimpor" dan "mengekspor" standarstandar dan praktik-praktik akuntansi.

\section{DAFTAR PUSTAKA}

Almilia L.S., 2010, Overview Roadmap Konvergensi IFRS 2012 dan Perkembangan PSAK di Indonesia, Bahan Ajar Mata Kuliah Pelaporan dan Akuntansi Keuangan, PPAk Universitas Sanatha Dharma

Astika I. B. P., Kontribusi Teori Kepentingan Kelompok dalam Standar Akuntansi Keuangan, Jurusan Akuntansi Fakultas Ekonomi Universitas Udayana. Diakses Januari 2011

Chariri A dan Hendero S K S., 2010, menguji kualitas standar akuntansi Hasil Adopsi IFRS: studi empiris pada PSAK N0. 55 (Revisi 2006), SNA XIII, Purwokerto

Earning Management, Universitas Surabaya. Diakses Januari 2011

Ferdian F., periodisasi perkembangan akuntansi di Indonesia, http://ferry.adsnimation.com/?p=18. Diakses Januari 2011

Jumantoro B.A., sejarah akuntansi Indonesia, http://bayuthejakers.blogspot.com/201 0/01/sejarah-akuntansi-indonesia.html. Diakses Januari 2011

Puspitasari, 2010, Pengaruh Informasi Akuntansi Terhadap Harga Saham, Fakultas Ekonomi Universitas 
Muhammadiyah Surakarta. Diakses Januari 2011

Sejarah standar akuntansi keuangan sejak tahun 1994

Siddharta I.T. dkk, 2002, Kata Pengantar Dewan Standar Ikatan Akuntan Indonesia

SAK, 2002, Pendahuluan Kerangka dasar penyusunan dan penyajian laporan keuangan

Sunardi, perkembangan akuntansi di Indonesia, tugas mata kuliah seminar akuntansi, fakultas ekonomi universitas pancasakti Tegal. Diakses Januari 2011

Widarsono, A, Sebuah tinjauan: perkembangan akuntansi internasional, UPI BHMN Bandung. Diakses Januari 2011

Sonoto.J, 2011, Review Telaah Kritis Perkembangan Akuntansi di Indonesia dan Dampaknya Pada Bursa Saham Indonesia, Tugas Individual Pelaporan Dan Akuntansi Keuangan, Program Pendidikan Profesi Akuntansi Fakultas Ekonomi Universitas Sanata Dharma 